\title{
Testosterone as a prospective predictor of pathological Gleason score and pathological stage in prostate cancer
}

\author{
Henrieta Drobková1,2, Jana Jurečeková ${ }^{3}$, Marián Grendár ${ }^{3}$, Ján Kliment Jr. ${ }^{1}$, Erika Halašová2,3 \\ and Ján Kliment ${ }^{1}$ \\ ${ }^{1}$ Department of Urology, Jessenius Faculty of Medicine in Martin and University Hospital Martin, Comenius University in \\ Bratislava, Martin, Slovakia \\ ${ }^{2}$ Department of Medical Biology, Jessenius Faculty of Medicine in Martin, Comenius University in Bratislava, Martin, \\ Slovakia \\ ${ }^{3}$ Biomedical Center Martin, Jessenius Faculty of Medicine in Martin, Comenius University in Bratislava, Martin, Slovakia
}

\begin{abstract}
The aim of the study was to assess the relationship between preoperative circulating levels of total serum testosterone and pathological Gleason score and pathological stage in prostate cancer patients who underwent radical retropubic prostatectomy. The levels of total serum testosterone were measured in the morning just before surgery in a group of 201 prostate cancer patients. Multinomial logistic regression models were used to model the association between total preoperative testosterone (individually or in combination with other preoperative predictors such as age, PSA, clinical stage and biopsy Gleason score) and pathological Gleason score, pathological stage in prostate cancer patients. The association between age and total testosterone was modelled by robust regression. The total serum testosterone, in combination with other prognostic factors (age, PSA, clinical stage and biopsy Gleason score) in models, was not statistically significant predictor of pathological Gleason score and pathological stage. The highly significant relationship between age and preoperative total testosterone was observed $(p=0)$. In prostate cancer patients, the level of total serum testosterone increased with age. In conclusion, total testosterone is not a statistically significant predictive factor for pathological Gleason score and pathological stage.
\end{abstract}

Key words: Prostate cancer — Total serum testosterone - Pathological Gleason score — Pathological stage - Age

\section{Introduction}

Androgens, male sexual hormones from the group of steroid hormones, have a central role in normal development, growth and maintenance of the physiological function of the prostate (Wilson 2011).

The most important androgens in males are testosterone and dihydrotestosterone. Testosterone is the principal androgen in circulation, while dihydrotestosterone is the primary nuclear androgen and the most potent androgen in

Correspondence to: Henrieta Drobková, Department of Urology, Jessenius Faculty of Medicine in Martin and University Hospital Martin, Comenius University in Bratislava, Kollárova 2, 03601 Martin, Slovakia

E-mail: henrieta.drobkova@gmail.com tissue. Approximately $90-95 \%$ of testosterone is produced by the Leydig cells of the testis and the remaining portion is produced in the adrenal cortex (Price and Hsing 2010). In both tissues the androgens are produced by the predominant pathway - the gamma-5 metabolic pathway (Lindzey et al. 1994; Martin and Coffey 1998). The most of the testosterone (more than 95\%) is bound with high affinity to sex-hormone binding globulin (SHBG) (44\% of testosterone), and with low affinity to albumin (54\% of testosterone) (Price and Hsing 2010; Chandrasekar et al. 2015). Only a small fraction (1-2\%) of the total circulating testosterone is a free and biologically active form (Rove et al. 2014). Dihydrotestosterone (DHT) is produced from testosterone in the cells of prostate tissue by an enzyme $5 a$-reductase.

Androgens are acting through the androgen receptor and have an important role in prostate cancer. The 
essential function of the androgen receptor is to induce growth of the male urogenital structures including prostate, through the activation of androgen-responsive genes. DHT is the most important mitogenic factor in the prostate because it is able to bind to androgen receptors and influence the gene transcription in the nucleus (Price and Hsing 2010). The testosterone, in comparison with DHT, is able to bind to androgen receptors in the nucleus with lower affinity. DHT forms a more stable receptor-ligand complex (Martin and Coffey 1998). Once the androgen receptor binds to androgen, it enters an active state and undergoes transactivation (Debes and Tindall 2002). The elevated activation of the androgen receptor, in normal prostatic tissue as well as prostate cancer tissue, can lead to enhanced cell proliferation, decreased apoptosis and other angiogenic events. It may be associated with increased risk of development of prostate cancer or progression of the disease. Therefore prostate cancer can be considered as disease-dependent on androgen receptors (Rove et al. 2014).

From birth to puberty, the prostate remains small and immature. During puberty the prostate enlarges up to 10-times compared to the prepubertal size due to increased androgen production (Swyer 1944). Later, the production of androgens (including testosterone) decreases with age (Matsumoto 2003).

In 1941, Huggins and Hodges, after observing the benefits of castration in patients with metastatic prostate cancer, showed that both normal cells as well as tumour cells of the prostate are androgen-dependent (Huggins and Hodges 1941). Later numerous clinical articles and the results of basic research have confirmed the role of androgens in the pathogenesis and progression of prostate cancer, eventually the dependence of prostate cancer on the androgen signalling pathway. Androgens can cause the growth of prostate cancer cells. Androgen deprivation results in the death of tumour cell and tumour regression.

However, there are conflicting clinical data about the role of endogenous testosterone in the development and progression of prostate cancer and its possible predictive power. Several studies have identified no association between the levels of total testosterone and the risk of prostate cancer development or progression. In many studies, the progression of the disease was associated with low or, on the contrary, high levels of total serum testosterone. The association between testosterone levels, prostate cancer risk and progression of prostate cancer is still unclear. These observations prompted us to analyse the association between preoperative total serum testosterone and pathological Gleason score, pathological stage in prostate cancer patients who underwent radical retropubic prostatectomy. The relationship between patient age and total serum testosterone was also evaluated.

\section{Material and Methods}

\section{Study populations}

The retrospective analysis is based on a group of 201 prostate cancer patients who underwent radical retropubic prostatectomy with or without pelvic lymphadenectomy during the period 2010-2016. None of these patients had received preoperative neoadjuvant hormonal therapy.

\section{Measurements of hormone and other data}

All blood samples for testing of total testosterone were taken from each patient in the morning between 7:00 a.m.-10:00 a.m. after a night of fasting just before surgery, in order to avoid any potential methodological flaws caused by circadian variations in concentrations of testosterone. All blood samples were examined in the same laboratory. Preoperative levels of total serum testosterone were measured by a chemiluminescence immunoassay. Preoperative data including age, total serum prostate specific antigen (PSA), clinical stage and biopsy Gleason score were assessed in all patients. Postoperative data include pathological Gleason score and pathological stage. The 2009 TNM classification of prostate cancer (Sobin et al. 2010) was used to define clinical stage and pathological stage. Biopsy Gleason score and pathological Gleason score were defined according to Gleason scoring system (Epstein et al. 2005, 2016).

\section{Statistical analysis}

The obtained data were evaluated with a number of statistical methods and analysis. The characteristics of the cohort of patients and categorized groups of patients were made by applying descriptive statistics (minimum, $1^{\text {st }}$ quartile, median, mean, $3^{\text {rd }}$ quartile, maximum, standard deviation, interquartile range). According to pathological Gleason score (pGS) in accordance with D'Amico risk of progression classification (D'Amico et al. 1998), we divided patients into following groups: 1) low-risk prostate cancer (pGS $\leq 6) ; 2$ ) intermediaterisk prostate cancer ( $\mathrm{pGS}=7$ ); 3) high-risk prostate cancer (pGS $\geq 8$ ). Based on pathological stage we divided patients into following groups: 1) tumour localized only in prostate (pT2a, pT2b, pT2c); 2) extracapsular tumour extension with infiltrated bladder neck (pT3a); 3) tumour invades seminal vesicles and other neighbouring structures (pT3b-pT4).We used ANOVA to test whether the mean value of total serum testosterone is the same in all three groups of patients stratified according to pathological Gleason score or pathological stage. Multinomial logistic regression models were used to model the association between total preoperative testosterone (individually or in combination with other predictors such as age, preoperative PSA, clinical stage and biopsy Gleason 
Table 1. The characteristics of patients in terms of age, PSA and total serum testosterone

\begin{tabular}{lcccccccc}
\hline & Min. & $1^{\text {st }} \mathrm{Qu}$. & Median & Mean & $3^{\text {rd }}$ Qu. & Max. & SD & IQR \\
\hline Age (years) & 46 & 58 & 62 & 61.52 & 65 & 77 & 5.445 & 7 \\
PSA (ng/ml) & 1,35 & 5.17 & 7.64 & 9.351 & 11.61 & 36.63 & 6.034 & 6.44 \\
TT (ng/ml) & 1.03 & 2.23 & 2.91 & 2.995 & 3.5 & 10.52 & 1.117 & 1.27 \\
\hline
\end{tabular}

PSA, prostate specific antigen; TT, total testosterone; Min, minimum; $1^{\text {st }} \mathrm{Qu}$, first quartile; $3^{\text {rd }} \mathrm{Qu}$, third quartile; Max, maximum; SD, standard deviation; IQR, interquartile range.

score), pathological Gleason score and pathological stage in prostate cancer patients. The association between age and total testosterone was modelled by robust regression. All statistical tests were performed with R version 3.2.3 (201512-10) (R Core Team 2015). All these tests were two-sided and $p<0.05$ was considered statistically significant.

\section{Results}

Main clinical and biochemical characteristics of the entire cohort of prostate cancer patients $(n=201)$ are reported in the Table 1 .

Table 2 presents the data related to the relative abundance $(n)$ for stratified groups of patients according to pathological stage and pathological Gleason score.

In the cohort of patients were men aged 46-77 years. We have found that the relationship between age and preoperative total serum testosterone is highly significant $(p=0)$. The levels of total testosterone are rising with increasing age. The increase in age by one year is associated with approximately $4.7 \%$ increase in total testosterone. The association is shown in Figure 1.

Assessment of the potential relationship between preoperative level of serum total testosterone and pathological Gleason score

Characteristics of groups of patients categorized according to pathological Gleason score, concerning the levels of total

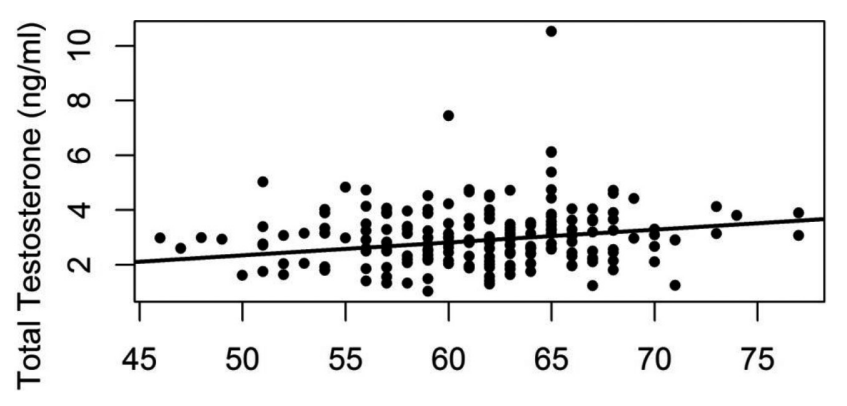

Age (years)

Figure 1. The association between age of prostate cancer patients and total serum testosterone.
Table 2. The relative abundance of categorized groups of patients

\begin{tabular}{lcc}
\hline & $n$ & $n(\%)$ \\
\hline Pathological stage & & \\
\hline pT2a, pT2b, pT2c & 115 & 57 \\
pT3a & 48 & 24 \\
pT3b, pT3c, pT4 & 38 & 19 \\
\hline Pathological Gleason score & & \\
\hline pGS $\leq 6$ & 47 & 23.4 \\
pGS $=7$ & 127 & 63.2 \\
pGS $\geq 8$ & 27 & 13.4 \\
\hline
\end{tabular}

$n$, relative abundance; $\mathrm{pT}$, pathological stage; $\mathrm{pGS}$, pathological Gleason score.

serum testosterone, is presented in the Table 3. The levels of total testosterone are in the range of $1.03-10.52 \mathrm{ng} / \mathrm{ml}$.

We observed that all three groups have almost identical total testosterone levels only with a slight increase in the median of total testosterone. The ANOVA test has confirmed that the mean value of total serum testosterone does not significantly differ between three groups of patients categorized according to pathological Gleason score $(p=0.857)$.

Subsequently, with respect to the potential use of total testosterone as a prospective predictor of pathologic Gleason score, we evaluated a possible association between total serum testosterone and pathological Gleason score by the multinomial logistic regression model. Based on the results, we can conclude that total serum testosterone is not a statistically significant predictor of pathological Gleason score $(p=0.429)$. Total testosterone remained statistically nonsignificant even when the other preoperative prognostic factors (age, PSA, clinical stage and biopsy Gleason score) were used in the model $(p=0.756)$. In this model there are two statistically significant predictors PSA $(p=0.024)$ and biopsy Gleason score $(p=0)$.

Assessment of the potential relationship between preoperative level of serum total testosterone and pathological stage

Characteristic of groups of patients categorized according to pathological stage, in the terms of total serum testosterone 
levels, is presented in the Table 3. The levels of total testosterone are in the range of $1.03-10.52 \mathrm{ng} / \mathrm{ml}$.

We have observed that all three groups, similarly as in patients categorized according to pathological Gleason score, have almost identical total testosterone levels only with a slight increase in the median of total testosterone. The ANOVA test has confirmed that the mean value of total serum testosterone does not significantly differ between three groups of patients categorized according to pathological stage $(p=0.848)$.

Subsequently, with respect to the potential use of total testosterone as a prospective predictor of pathologic stage, we evaluated a potential association between total serum testosterone and pathological stage by the multinomial logistic regression model. In the model we also included other preoperative prognostic factors, such as age, PSA, clinical stage and biopsy Gleason score. Results have showed that total serum testosterone in combination with other prognostic factors did not achieve statistically significant predictor status of pathological stage $(p=0.904)$. This model pointed to three statistically significant predictors: PSA $(p=0)$, biopsy Gleason score $(p=0)$ and clinical stage $(p=0.039)$. Akaike Information Criterion model selection was also used to find possible predictors. According to this criterion, total serum testosterone was not found to be a useful predictor of pathological stage. Only PSA and biopsy Gleason score were selected as predictors of pathological stage. According to OR (Odds Ratio) we can state that a unit increase of PSA rises the risk of moving from the first group (patients with pT2a, pT2b, pT2c) to the second group (pT3a) by $10.8 \%$ and also a unit increase of PSA rises the risk of moving from the first group (patients with pT2a, pT2b, pT2c) to the third group (pT3b-pT4) by $13.37 \%$.

\section{Discussion}

Androgens have a function in the differentiation and growth of prostate and therefore are considered to play a key role in prostate carcinogenesis. The relation between the prostate cancer and the androgen signalling pathway was demonstrated for the first time in 1941 (Huggins and Hodges 1941). Since then the prostate cancer has been considered as an androgen-dependent tumour.

Currently, only PSA, clinical stage and biopsy Gleason score are used as common preoperative prognostic factors in the diagnosis and the treatment of prostate cancer. Various studies indicate the important role of these factors in prediction of the pathological condition after radical prostatectomy in prostate cancer patients (Salonia et al. 2011b, 2012; Léon et al. 2015). In our study, we have also confirmed that PSA and biopsy Gleason score are important predictors of pathological Gleason score and pathological stage, but the clinical stage has proved to be significant predictor only of the pathological stage. Other biochemical, hormonal and pathological criteria and more precise preoperative markers are also considered to be helpful to distinguish low-risk prostate cancer from the high-risk prostate cancer. Testosterone is nowadays frequently studied as one of the possible predictors of the risk of the prostate cancer development and progression. The precise association between the level of total serum testosterone (TT), free testosterone (FT), bioavailable testosterone (BT) and pathological signs of prostate cancer is not still fully elucidated and published studies present contradictory results.

Many large studies have found no association between total serum testosterone levels and the overall risk of the prostate cancer (Stattin et al. 2004; Platz et al. 2005; Travis et al. 2007; Endogenous Hormones and Prostate Cancer Collaborative Group et al. 2008; Muller et al. 2012). On the other hand, the association between serum androgens and certain subtypes of prostate cancer has been observed (Price and Hsing 2010). The relationship between the level of total testosterone and the progression of the disease has been also examined in several studies (Isom-Batz et al. 2005; Travis et al. 2007; Pierorazio et al. 2010; Salonia et al. 2011b; Xylinas et al. 2011; Albisinni et al. 2012; García-Cruz et al. 2012; Salonia

Table 3. The characteristic of categorized groups of patients according to pathological Gleason score and pathological stage in terms of levels of total testosterone

\begin{tabular}{lllllrr}
\hline & Min. & $1^{\text {st }} \mathrm{Qu}$. & Median & Mean & $3^{\text {rd }}$ Qu. & Max. \\
\hline Pathological Gleason score & & & & & & \\
\hline pGS $\leq 6$ & 1.33 & 2.16 & 2.84 & 2.944 & 3.375 & 6.13 \\
pGS=7 & 1.03 & 2.215 & 2.9 & 2.994 & 3.555 & 10.52 \\
pGS $\geq 8$ & 1.29 & 2.575 & 3.19 & 3.094 & 3.625 & 4.66 \\
\hline Pathological stage & & & & & 3.375 & 10.52 \\
\hline pT2a, pT2b, pT2c & 1.03 & 2.22 & 2.91 & 3.012 & 3.842 & 4.83 \\
pT3a & 1.41 & 2.09 & 2.985 & 3.029 & 3.402 & 6.1 \\
pT3b, pT3c, pT4 & 1.29 & 2.49 & 2.93 & 2.902 & 3.25 \\
\hline
\end{tabular}

pGS, pathological Gleason score; pT, pathological stage; Min, minimum; $1^{\text {st }} \mathrm{Qu}$, first quartile; $3^{\text {rd }} \mathrm{Qu}$, third quartile; Max, maximum. 
et al. 2012; Léon et al. 2015; Ferro et al. 2017) and conflicting data have been detected. Because of the contradictory results from previous studies, we have investigated a possible relation between total serum testosterone, pathological Gleason score and pathological stage in the prostate cancer patients who underwent radical prostatectomy. We have considered serum testosterone level as possible predictor of prostate cancer progression and aggressiveness individually as well as together with other predictors (age, PSA levels, biopsy Gleason score, clinical stage).

In our study, we have not found a statistically significant association between the levels of total testosterone and pathological Gleason score or pathological stage. Based on these results, we could state that the level of total preoperative serum testosterone (neither alone nor in combination with other possible predictors) is not a statistically significant predictor of pathological Gleason score or pathological stage.

Similar results were described in several studies containing a heterogeneous group of patients with large spectrum of clinical stages such as in our study, not only patients with localized prostate cancer. These studies stated that there was no significant association between total serum testosterone levels and the low-risk/high-risk prostate cancer, high grade cancer (with a poor prognosis) or positive surgical margins after radical prostatectomy (Sher et al. 2009; Pierorazio et al. 2010; Salonia et al. 2011b; Salonia et al. 2012).

When the relation between total testosterone and the preoperative prognostic factors was examined, it was revealed that neither total nor free testosterone levels are statistically significantly associated with low grade or high grade prostate cancer (Albisinni et al. 2012).

On contrary to our observations, other studies have reported an association between the levels of preoperative circulating total testosterone and advanced pathological stage. The high-risk prostate cancer (with advanced pathological stage or high grade or positive surgical margins) has been associated rather with low than high levels of total serum testosterone (Schatzl et al. 2001; Massengill et al. 2003; Isom-Batz et al. 2005; Teloken et al. 2005; Xylinas et al. 2011; Léon et al. 2015). On the other hand, not all of the records have confirmed these observations (Salonia et al. 2011a, 2012). Salonia et al. (2012), based on the analysis of 665 men, stated that no total testosterone levels reached the status of a statistically significant predictor of the presence of the positive surgical margins. In some studies a significant association between the low preoperative level of total serum testosterone and the aggressive postoperative pathological condition (high grade and/or advanced pathological stage - extraprostatic enlargement) has been found in men with clinically localised prostate cancer who underwent radical prostatectomy (Massengill et al. 2003; Isom-Batz et al. 2005; Xylinas et al. 2011; Léon et al. 2015). The study, which has evaluated the association between total testosterone and the prognostic factors of the pathological condition prior to application of the surgical treatment, has found a link between low level of total testosterone $(<346 \mathrm{ng} / \mathrm{dl})$ and poor prognostic factors (higher clinical stage and higher risk of disease progression - higher grading). It was based on the stratification of patients according to biopsy Gleason score (bGS $\leq 7$ and bGS $>7$ ) (García-Cruz et al. 2012). In one of the mentioned studies, all of the patients (with and without neoadjuvant treatment - 326 patients) as well as patients without hormone treatment (59 patients) were analysed. The authors have found the correlation between lower levels of total testosterone and the adverse pathological stage whereas higher levels of total testosterone correlated with the disease limited to the prostate (Isom-Batz et al. 2005). Although in Leon's study it is initially indicated that there is a link between a low level of total testosterone and the presence of higher pathological Gleason score ( $\mathrm{pGS} \geq 7$ ), further analysis has showed that only the bioavailable testosterone and free testosterone are significant predictors of the pathological Gleason score ( $\mathrm{pGS} \geq 7$ ). Low levels of bioavailable testosterone $(\mathrm{BT}<1.5 \mathrm{ng} / \mathrm{ml})$ and free testosterone $(\mathrm{FT}<65 \mathrm{pg} / \mathrm{ml})$ significantly correlated with the Gleason score upgrading. However, a link between the hypogonadism $(\mathrm{TT}<3 \mathrm{ng} / \mathrm{ml})$ and the disease with a high grade has not been found. Also, the nonsignificant correlation between low levels of circulating testosterone and extracapsular extension, testis invasion, positive surgical margins or Gleason score upgrading has been found (Léon et al. 2015). In comparison with the above mentioned results we can also find different observations in the literature which indicate a higher probability of developing the disease not confined to the prostate (pT3-pT4) in patients with a decreased level of total serum testosterone ( $\mathrm{TT}<3 \mathrm{ng} / \mathrm{ml}$ ) (Xylinas et al. 2011). There has been found a significant association between low levels of testosterone ( $\mathrm{TT}<300 \mathrm{ng} / \mathrm{dl}$ ) and upgrading, upstanding, adverse disease and positive surgical margins in patients with the low-risk prostate cancer who were actively monitored (Ferro et al. 2017). In the literature we can find to a lesser extent the opposite findings according to which the risk of high-risk prostate cancer (with high grade $\mathrm{pGS} \geq 8$ ) is associated with high preoperative levels of total serum testosterone (division of patients according to median in groups with $\mathrm{TT}>15.5$ $\mathrm{nmol} / \mathrm{l}$ and TT $\leq 15.5 \mathrm{nmol} / \mathrm{l}$ ) (Porcaro et al. 2014). The results of these studies do not correspond with our results, however, we examined only total serum testosterone levels. The evaluation of variable forms of testosterone such as free testosterone or bioavailable testosterone, was not the subject of our study.

The data in the presented studies (regarding levels of testosterone, pathological Gleason score and pathological stage) are also often evaluated according to different criteria of division whereby there can be differences in the results among different epidemiological studies. Other reasons that 
could have contributed to the different results are a diversity of methods used for the measurement of data, interpersonal variability and heterogeneity of the prostate cancer. For these reasons, our results have confirmed findings of some studies and contradicted results of other studies.

The age is considered as one of the risk factors of the prostate cancer and serum testosterone levels are not constant during the lifetime, too. This fact complicates the examination of the interaction between the serum hormone levels and the prostate cancer. Although the serum testosterone level decreases with age in men, there is a tendency for an increase in the incidence of prostate cancer (Isbarn et al. 2009; Pierorazio et al. 2010; Porcaro et al. 2014). The exact level of testosterone in older men, which would be significant in the terms of the effect on prostate cancer etiopathogenesis, is not yet known. Thus, we have focused also on discovering the relation between the age and the level of total serum testosterone in men with the prostate cancer. We observed strongly significant relation between the age and the levels of total serum testosterone. Based on the results, we can conclude that in men diagnosed with the prostate cancer the level of total serum testosterone increases with age, although in healthy men in a postpuberty period it gradually decreases (Matsumoto 2003). While in younger men a certain amount of androgens is inevitable, in older men diagnosed with the prostate cancer, androgens might have a harmful effect because they support the proliferation of the prostate cancer cells and thus the progression of the disease. The cause of elevated total testosterone levels is not known yet. We can only speculate that it is increased based on certain mechanisms and then it stimulates proliferation of tumour cells in men with the prostate cancer. According to another study, the duration of the androgen exposure or a significant decrease in the level of serum testosterone associated with age can play important role in the prostate cancer development (Lasselin et al. 2013).

When using the multinomial regression model, while evaluating several prognostic factors (total testosterone, age, prostatic specific antigen, clinical stage, biopsy Gleason score) in terms of their use as possible predictors of pathological Gleason score and pathological stage, we have not found a significant association between the age and pathological Gleason score or the pathological stage. A similar finding has also been reported in other studies (García-Cruz et al. 2012; Porcaro et al. 2014; Léon et al. 2015). In contrast to our results, Brassell et al. (2011) stated that the pathological stage, upgrading and positive surgical margins were significantly higher in older patients (age $\geq 70$ ) who had undergone radical prostatectomy. The authors explained the obtained results as a natural progression of undiagnosed prostate cancer or hormonal changes associated with the age. Another study highlighted the strong connection between the age, levels of testosterone and the probability of the development of the high-risk disease (Pierorazio et al. 2010). They report that high or even normal serum testosterone levels could relate to the development of the high-risk prostate cancer in older men.

The advantage of our study is that we were observing a homogeneous group of patients of the same race which had a large spectrum of clinical stages and pathological stages or grades. When ascertaining the associations, we have not been evaluating the testosterone levels in relation to preoperative prognostic factors but rather in relation to the pathological Gleason score. Gleason score is considered to be the most important prognostic prostate cancer factor because it predicts the biochemical reoccurrence, formation of metastasis and prostate cancer - specific mortality better than the basic PSA, PSA doubling time and the pathological stage (Hull et al. 2002; Freedland et al. 2005; Cuzick et al. 2006).

The limitation of this study is the single assessment of concentrations of circulating serum testosterone in every patient which may not be fully clinically reliable. In these patients, there have not been evaluated clinical data such as diabetes, thyroid disease, hyperprolactinemia, hypoalbuminemia, liver disease, obesity and metabolic syndrome, which may affect some biochemical data and thereby distort the results. When analysing the connection between serum androgens and the prostate cancer it would be appropriate to focus, besides total serum testosterone, also on its variable forms - free testosterone and bioavailable testosterone. In general, these forms reflect the clinical situation more accurately than total testosterone (Salonia et al. 2011b).

In conclusion, we have found the strongly significant relation between the age and the level of total serum testosterone in prostate cancer patient. We can state, that androgens acting through the androgen receptors have an important role in prostate cancer. On the other hand, total serum testosterone is not statistically significant predictive factor for pathological Gleason score and pathological stage. Some studies suggest that variable forms of testosterone such as free testosterone, bioavailable and percentage of free testosterone, rather than levels of total testosterone, what might be associated with pathological condition (pathological Gleason score and pathological stage) of prostate cancer. Further studies are needed to investigate the role of testosterone and its variable forms in the development of prostate cancer and also their prognostic potential because these data can be useful for assessing treatment response and the choice of optimal treatment in prostate cancer patients.

Acknowledgements: This publication is the result of the project implementation: "CENTER OF TRANSLATIONAL MEDICINE", ITMS: 26220220021. This work was also supported by the project “Biomedical Center Martin”, ITMS code: 26220220187. 


\section{References}

Albisinni S., Nunzio C. D., Tubaro A., Barry W. T., Banez L. L., Freedland S. J. (2012): Greater percent-free testosterone is associated with high-grade prostate cancer in men undergoing prostate biopsy. Urology 80, 162-168 https://doi.org/10.1016/j.urology.2012.01.068

Brassell S. A., Rice K. R., Parker P. M., Chen Y., Farrell J. S., Cullen J., McLeod D. G. (2011): Prostate cancer in men 70 years old or older, indolent or aggressive: clinicopathological analysis and outcomes. J. Urol. 185, 132-137 https://doi.org/10.1016/j.juro.2010.09.014

Chandrasekar T., Yang J. C., Gao A. C., Evans C. P. (2015): Mechanisms of resistance in castration-resistant prostate cancer (CRPC). Transl. Androl. Urol. 4, 365-380

Cuzick J., Fisher G., Kattan M. W., Berney D., Oliver T., Foster C. S., Moller H., Reuter V., Fearn P., Eastham J., Scardino P., Transatlantic Prostate Group (2006): Long-term outcome among men with conservatively treated localised prostate cancer. Br. J. Cancer 95, 1186-1194 https://doi.org/10.1038/sj.bjc.6603411

D‘Amico A. V., Whittington R., Malkowicz S. B., Schultu D., Blank K., Broderick G. A., Tomaszewski J. E., Renshaw A. A., Kaplan I., Beard C. J., Wein A. (1998): Biochemical outcome after radical prostatectomy, external beam radiation therapy, or interstitial radiation therapy for clinically localized prostate cancer. JAMA 280, 969-974 https://doi.org/10.1001/jama.280.11.969

Debes J. D., Tindall D. J. (2002): The role of androgens and the androgen receptor in prostate cancer. Cancer Lett. 187, 1-7 https://doi.org/10.1016/S0304-3835(02)00413-5

Endogenous Hormones and Prostate Cancer Collaborative Group, Roddam A. W., Allen N. E., Appleby P., Key T. J. (2008): Endogenous sex hormones and prostate cancer: a collaborative analysis of 18 prospective studies. J. Natl. Cancer. Inst. 100, $170-183$ https://doi.org/10.1093/jnci/djm323

Epstein J. I., Allsbrook Jr. W. C., Amin M. B., Egevad L. L., ISUP Grading Committee (2005): The 2005 International Society of Urological Pathology (ISUP) Consensus Conference on Gleason Grading of Prostatic Carcinoma. Am. J. Surg. Pathol. 29, $1228-1242$ https://doi.org/10.1097/01.pas.0000173646.99337.b1

Epstein J. I., Egevad L., Amin M. B., Delahunt B., Srigley J. R., Humphrey P. A., Grading Committee (2016): The 2014 International Society of Urological Pathology (ISUP) consensus conference on Gleason grading of prostatic carcinoma: definition of grading patterns and proposal for a new grading system. Am. J. Surg. Pathol. 40, 244-252

Ferro M., Lucarelli G., Bruzzese D., Di Lorenzo G., Pedona S., Autorino R., Cantiello F., La Rocca R., Busetto G. M., Cimmino A. et al. (2017): Low serum total testosterone level as a predictor of upstaging and upgrading in low-risk prostate cancer patients meeting the inclusion criteria for active surveillance. Oncotarget 8, 18424-18434 https://doi.org/10.18632/oncotarget.12906

Freedland S. J., Humphreys E. B., Mangold L. A., Eisenberger M., Dorey F. J., Walsh P. C., Partin A. W. (2005): Risk of prostate cancer-specific mortality following biochemical recurrence after radical prostatectomy. JAMA 294, 433-439

https://doi.org/10.1001/jama.294.4.433

García-Cruz E., Piqueras M., Huguet J., Peri L., Izquierdo L., Musquera M., Franco A., Alvarez-Vijande R., Ribal M. J., Alcaraz A. (2012): Low testosterone levels are related to poor prognosis factors in men with prostate cancer prior to treatment. BJU Int. 110, E541-E546 https://doi.org/10.1111/j.1464-410X.2012.11232.x

Huggins C., Hodges C. V. (1941): Studies on prostate cancer. I: The effect of castration, of estrogen and of androgen injection on serum phosphatases in metastatic carcinoma of the prostate. Cancer Res. 1, 293-297

Hull G. W., Rabbani F., Abbas F. A., Wheeler T. M., Kattan M. W., Scardino P. T. (2002): Cancer control with radical prostatectomy alone in 1,000 consecutive patients. J. Urol. 167, 528-534 https://doi.org/10.1016/S0022-5347(01)69079-7

Isbarn H., Pinthus J. H., Marks L. S., Montorsi F., Morales A., Morgentaler A., Schulman C. (2009): Testosterone and prostate cancer: revisiting old paradigms. Eur. Urol. 56, 48-56 https://doi.org/10.1016/j.eururo.2009.03.088

Isom-Batz G., Bianco F. J. Jr., Kattan M. W., Mulhall J. P., Eastham J. A. (2005): Testosterone as a predictor of pathological stage in clinically localized prostate cancer. J. Urol. 173, 1935-1937 https://doi.org/10.1097/01.ju.0000158040.33531.e7

Lasselin J., Drouin S. J., Champy C. M., Leon P., Casenave J., Cussenot O., Bitker M. O., Roupret M. (2013): Influence of plasmatic testosterone during natural history of prostate cancer: a review. Prog. Urol. 23, 438-443 https://doi.org/10.1016/j.purol.2013.01.007

Léon P., Seisena T., Cussenot O., Drouin S. J., Cattarino S., Comperat E., Renard-Penna R., Mozer P., Bitker M. O., Roupret M. (2015): Low circulating free and bioavailable testosterone levels as predictors of high-grade tumors in patients undergoing radical prostatectomy for localized prostate cancer. Urol. Oncol. 33, 384.e21-384.e27 https://doi.org/10.1016/j.urolonc.2014.11.010

Lindzey J., Kumar M. V., Grossmann M., Young C., Tindall D. J. (1994): Molecular mechanisms of androgen action. Vitam. Horm. 49, 383-432

https://doi.org/10.1016/S0083-6729(08)61151-6

Martin A. W., Coffey D. S. (1998): The molecular biology, endocrinology, and physiology of the prostate and seminal vesicles. In: Campbell's Urology. (Eds. Walsh P. C., Bretik A., Vaughan E. D. and Wein A. J.) pp. 1381-1428, W. B. Saunders, Philadelphia

Massengill J. C., Sun L., Moul J. W., Wu H., McLeod D. G., Amling C., Lance R., Foley J., Sexton W., Kusuda L., Chung A., Soderdahl D., Donahue T. (2003): Pretreatment total testosterone level predicts pathological stage in patients with localized prostate cancer treated with radical prostatectomy. J. Urol. 169, 1670-1675

https://doi.org/10.1097/01.ju.0000062674.43964.d0

Matsumoto A. M. (2003): Fundamental aspects of hypogonadism in the aging male. Rev. Urol. 5, S3-S10

Muller R. L., Gerber L., Moreira D. M., Andriole G., CastroSantamaria R., Freedland S. J. (2012): Serum testosterone and dihydrotestosterone and prostate cancer risk in the placebo 
arm of the reduction by dutasteride of prostate cancer events trial. Eur. Urol. 62, 757-764

https://doi.org/10.1016/j.eururo.2012.05.025

Pierorazio P. M., Ferrucci L., Kettermann A., Longo D. L., Metter E. J., Carter H. B. (2010): Serum testosterone is associated with aggressive prostate cancer in older men: result from the Baltimore Longitudinal Study of Aging. BJU Int. 105, 824-829 https://doi.org/10.1111/j.1464-410X.2009.08853.x

Platz E. A., Leitzman M. F., Rifai N., Kantoff P. W., Chen Y. C., Stampfer M. J., Willett W. C., Giovannucci E. (2005): Sex steroid hormones and the androgen receptor gene CAG repeat and subsequent risk of prostate cancer in the prostatespecific antigen era. Cancer Epidemiol. Biomarkers Prev. 14, $1262-1269$ https://doi.org/10.1158/1055-9965.EPI-04-0371

Porcaro A. B., Petrozziello A., Ghimenton C., Migliorini F., Sava T., Caruso B., Romano M., Cavalleri S., Astibani W. (2014): Associations of pretreatment serum total testosterone measurements with pathology-detected Gleason score cancer. Urol. Int. 93, 269-278 https://doi.org/10.1159/000354621

Price D. K., Hsing A. W. (2010): Androgens and prostate cancer. In: Drug Management of Prostate Cancer. (Eds. Figg W., Chau C. H. and Small E. J.), pp. 53-59, Springer-Verlag, New York https://doi.org/10.1007/978-1-60327-829-4_4

R Core Team (2015): R: A language and environment for statistical computing. R Foundation for Statistical Computing. Vienna, Austria

Rove K. O., Crawford E. D., Perachino M., Morote J., Klotz L., Lange P. H., Andriole G. L., Matsumoto A. M., Taneja A. M., Taneja S. S. et al. (2014): Maximal testosterone suppression in prostate cancer - free vs total testosterone. Urology 83, 1217-1222 https://doi.org/10.1016/j.urology.2014.02.001

Salonia A., Gallina A., Abdollah F., Briganti A., Capitanio U., Suardi N., Farrari M., Raber M., Colombo R., Freschi M., Rigatti P., Montorsi F. (2012): Preoperative circulating sex hormones are not predictors of positive surgical margins at open radical prostatectomy. World J. Urol. 30, 533-539 https://doi.org/10.1007/s00345-011-0761-5

Salonia A., Gallina A., Briganti A., Abdollah F., Suardi N., Capitanio U., Freschi M., Rigatti P., Montorsi F. (2011a): Preoperative hypogonadism is not an independent predictor of high-risk disease in patients undergoing radical prostatectomy. Cancer 117, 3953-3962 https://doi.org/10.1002/cncr.25985

Salonia A., Gallina A., Briganti A., Suardi N., Capitanio U., Abdollah F., Bertini R., Freschi M., Rigatti P., Montorsi F. (2011b): Circulating estradiol, but not testosterone, is a significant predictor of high-grade prostate cancer in patients undergoing radical prostatectomy. Cancer 117, 5029-5038 https://doi.org/10.1002/cncr.26136

Schatzl G., Madersbacher S., Thurridl T., Waldmüller J., Kramer G., Haitel A., Marberger M. (2001) High-grade prostate cancer is associated with low serum testosterone levels. Prostate 47, $52-58$ https://doi.org/10.1002/pros.1046

Sher D. J., Mantzoros C., Jacobus S., Regan N. M., Lee G. S., Oh W. K. (2009): Absence of relationship between steroid hormone levels and prostate cancer tumor grade. Urology 73, 356-361 https://doi.org/10.1016/j.urology.2008.07.068

Sobin L. H., Gospodarowicz M. K., Wittekind Ch. (2010): TNM Classification of Malignant Tumours. Seventh Edition 2009, Wiley-Blackwell, UK

Stattin P., Lumme S., Tenkanen L., Alfthan H., Jellum E., Hallmans G., Thoresen S., Hakulinen T., Luostarinen T., Lehtinen M. et al. (2004): High levels of circulating testosterone are not associated with increased prostate cancer risk: a pooled prospective study. Int. J. Cancer 108, 418-424 https://doi.org/10.1002/ijc.11572

Swyer G. I. (1944): Post-natal growth changes in the human prostate. J. Anat. 78, 130-145

Teloken C., Da Ros C. T., Caraver F., Weber F. A., Cavalheiro A. P., Graziottin T. M. (2005): Low serum testosterone levels are associated with positive surgical margins in radical retropubic prostatectomy: hypogonadism represents bad prognosis in prostate cancer. J. Urol. 174, 2178-2180 https://doi.org/10.1097/01.ju.0000181818.51977.29

Travis R. C., Key T. J., Allen N. E., Appleby P. N., Roddam A. W., Rinaldi S., Egevad L., Gann P. H., Rohrmann S., Linseisen J. et al. (2007): Serum androgens and prostate cancer among 643 cases and 643 controls in the European Prospective Investigation into Cancer and Nutrition. Int. J. Cancer 121, 1331-1338 https://doi.org/10.1002/ijc.22814

Wilson J. D. (2011): The critical role of androgens in prostate development. Endocrinol. Metab. Clin. North. Am. 40, 577-590 https://doi.org/10.1016/j.ecl.2011.05.003

Xylinas E., Ploussard G., Durand X., Fabre A., Salomon L., Allory Y., Vordos D., Hoznek A., Abbou C. C., de la Taille A. (2011): Low pretreatment total testosterone $(<3 \mathrm{ng} / \mathrm{mL})$ predicts extraprostatic disease in prostatectomy specimens from patients with preoperative localized prostate cancer. BJU Int. 107, 1400-1403 https://doi.org/10.1111/j.1464-410X.2010.09816.x

Received: March 31, 2017

Final version accepted: October 2, 2017 